\title{
DIGITALCOMMONS
}

$5-1-2014$

\section{Front Matter}

JMASM Editors

Follow this and additional works at: http://digitalcommons.wayne.edu/jmasm

\section{Recommended Citation}

Editors, JMASM (2014) "Front Matter," Journal of Modern Applied Statistical Methods: Vol. 13 : Iss. 1 , Article 1. DOI: $10.22237 /$ jmasm/1398916800

Available at: http://digitalcommons.wayne.edu/jmasm/vol13/iss1/1

This Front Matter is brought to you for free and open access by the Open Access Journals at DigitalCommons@WayneState. It has been accepted for inclusion in Journal of Modern Applied Statistical Methods by an authorized editor of DigitalCommons@WayneState. 


\title{
Journal of \\ Modern Applied Statistical Methods
}

\author{
Shlomo S. Sawilowsky \\ SENIOR EDITOR \\ College of Education \\ Wayne State University \\ Harvey Keselman \\ ASSOCIATE EDITOR EMERITUS \\ Department of Psychology \\ University of Manitoba
}

\author{
Jack Sawilowsky \\ EDITOR \\ Reason Statistical Consulting
}

\author{
Bruno D. Zumbo \\ ASSOCIATE EDITOR \\ Measurement, Evaluation, \\ \& Research Methodology \\ University of British Columbia
}

\author{
Vance W. Berger \\ ASSISTANT EDITOR \\ Biometry Research Group \\ National Cancer Institute
}

\author{
Todd C. Headrick \\ ASSISTANT EDITOR \\ Educational Psychology \\ \& Special Education \\ So. Illinois University- \\ Carbondale
}

Julie M. Smith, PhD

EDITORIAL ASSISTANT
Joshua Neds-Fox

EDITORIAL ASSISTANCE

\begin{abstract}
JMASM (ISSN 1538-9472, http://digitalcommons.wayne.edu/jmasm) is an independent, open access electronic journal, published biannually in May and November by JMASM Inc. (PO Box 48023, Oak Park, MI, 48237) in collaboration with the Wayne State University Library System. JMASM seeks to publish (1) new statistical tests or procedures, or the comparison of existing statistical tests or procedures, using computer-intensive Monte Carlo, bootstrap, jackknife, or resampling methods, (2) the study of nonparametric, robust, permutation, exact, and approximate randomization methods, and (3) applications of computer programming, preferably in Fortran (all other programming environments are welcome), related to statistical algorithms, pseudo- random number generators, simulation techniques, and self-contained executable code to carry out new or interesting statistical methods.
\end{abstract}

Journal correspondence (other than manuscript submissions) and requests for advertising may be forwarded to ea@jmasm.com. See back matter for instructions for authors. 


\title{
Journal of Modern Applied Statistical Methods
}

\author{
Vol. 13, No. 1 \\ \% May 2014 do \\ Table of Contents
}

Regular Articles

\begin{tabular}{|c|c|c|}
\hline $2-22$ & $\begin{array}{l}\text { Y. LIU } \\
\text { B. D. ZUMBO } \\
\text { A. D. WU }\end{array}$ & $\begin{array}{l}\text { Relative Importance of Predictors in Multilevel } \\
\text { Modeling }\end{array}$ \\
\hline $23-35$ & F. GEORGE & $\begin{array}{l}\text { A Comparison of Shape and Scale Estimators of } \\
\text { the Two-Parameter Weibull Distribution }\end{array}$ \\
\hline $36-54$ & $\begin{array}{l}\text { M. BHANDARY } \\
\text { K. FUJIWARA }\end{array}$ & $\begin{array}{l}\text { An Alternative Test for the Equality of Intraclass } \\
\text { Correlation Coefficients under Unequal Family } \\
\text { Sizes for Several Populations }\end{array}$ \\
\hline $55-70$ & $\begin{array}{l}\text { A. ALZAATREH } \\
\text { I. GHOSH } \\
\text { H. SAID }\end{array}$ & On the Gamma-Logistic Distribution \\
\hline $71-90$ & $\begin{array}{l}\text { E. N. COMAN } \\
\text { E. IORDACHE } \\
\text { L. DIERKER } \\
\text { J. FIFIELD } \\
\text { J. J. SCHENSUL } \\
\text { S. SUGGS } \\
\text { R. BARBOUR }\end{array}$ & $\begin{array}{l}\text { Statistical Power of Alternative Structural } \\
\text { Models for Comparative Effectiveness Research: } \\
\text { Advantages of Modeling Unreliability }\end{array}$ \\
\hline $91-109$ & $\begin{array}{l}\text { M. L. LESSER } \\
\text { M. B. AKERMAN }\end{array}$ & $\begin{array}{l}\text { An Exploratory Graphical Method for } \\
\text { Identifying Associations in } \\
\text { r x c Contingency Tables }\end{array}$ \\
\hline $110-139$ & $\begin{array}{l}\text { L. F. LEACH } \\
\text { R. K. HENSON }\end{array}$ & $\begin{array}{l}\text { Bias and Precision of the Squared Canonical } \\
\text { Correlation Coefficient Under Nonnormal Data } \\
\text { Conditions }\end{array}$ \\
\hline
\end{tabular}


Journal of Modern Applied Statistical Methods May 2014, Vol. 13, No. 1, ii-vi

\begin{tabular}{|c|c|}
\hline $140-156$ & $\begin{array}{l}\text { T. SHARAF } \\
\text { C. P. TSOKOS }\end{array}$ \\
\hline $157-173$ & $\begin{array}{l}\text { A. A. SMADI } \\
\text { J. J. JABER } \\
\text { A. G. AL-ZU'BI }\end{array}$ \\
\hline $174-186$ & $\begin{array}{l}\text { R. R. L. KANTAM } \\
\text { M. C. PRIYA } \\
\text { M. S. RAVIKUMAR }\end{array}$ \\
\hline $187-198$ & $\begin{array}{l}\text { S. KUMAR } \\
\text { M. VISWANATHAIAH }\end{array}$ \\
\hline
\end{tabular}

$199-222 \quad$ J. SUBRAMANI G. PRABAVATHY

$223-233$

$234-254$

$255-266$

$267-277$

V. RAMAKRISHNA M. S. RAVIKUMAR

$278-286$

$287-304$
R. R. L. KANTAM

A. RASHID

T. R. JAN

R. TAILOR

H. A. LONE

J. SUBRAMANI G. PRABAVATHY

NURWIANI S. SUNARYO SETIAWAN B. W. OTOK

A. PAK G. A. PARHAM M. SARAJ
Predicting Survival Time of Localized

Melanoma Patients Using Discrete Survival Time Method

Robustness of Several Estimators of the ACF of AR(1) Process With Non-Gaussian Errors

Likelihood Ratio Type Test for Linear Failure Rate Distribution vs. Exponential Distribution

Population Mean Estimation with Sub Sampling the Non-Respondents Using Two Phase Sampling

Two Parameter Modified Ratio Estimators with Two Auxiliary Variables for Estimation of Finite Population Mean with Known Skewness, Kurtosis and Correlation Coefficient

Separate Ratio-type Estimators of Population Mean in Stratified Random Sampling

Median Based Modified Ratio Estimators with Known Quartiles of an Auxiliary Variable

Ridge Regression in Calibration Models with Symmetric Padding Extension-Daubechies Wavelet Transform Preprocessing

Estimation and Testing in Type-II Generalized Half Logistic Distribution

A Compound of Geeta Distribution with Generalized Beta Distribution

Inference for the Rayleigh Distribution Based on Progressive Type II Fuzzy Censored Data 
Journal of Modern Applied Statistical Methods

May 2014, Vol. 13, No. 1, ii-vi

$305-328$

S. PUNDIR

R. AMALA

$329-338$

$339-353$

$354-366$

A. BHATTACHARJEE

$367-379$

G. SRINIVASA RAO

$380-396$

S. SINGH

S. A. SEDORY

$397-409$

Y. KAWASAKI

E. MIYAOKA

$410-430$

O. S. YAYA

O. I. SHITTU

$431-445$

O. I. SHITTU

K. A. ADEPOJU

$446-462$

S. S. GANGULY
ISSN $1538-9472$

Evaluation of Area Under the Constant Shape Bi-Weibull ROC Curve

Hierarchical Clustering with Simple Matching and Joint Entropy Dissimilarity Measure

Change Point Estimation for Pareto Type-II Model

Distance Correlation Coefficient: An Application with Bayesian Approach in Clinical Data Analysis

Estimation of Reliability in Multicomponent Stress-Strength Based on Generalized Rayleigh Distribution

Stochastic Randomized Response Model for a Quantitative Sensitive Random Variable

Comparison of Three Calculation Methods for a Bayesian Inference of Two Poisson Parameters

Specifying Asymmetric STAR models with Linear and Nonlinear GARCH Innovations: Monte Carlo Approach

On the Exponentiated Weibull Distribution for Modeling Wind Speed in South Western Nigeria

Robust Regression Analysis for Non-Normal Situations under Symmetric Distributions Arising in Medical Research

JMASM Algorithms and Code

$\begin{array}{ll}463-483 & \text { Y. PAN } \\ & \text { M. T. McBEE }\end{array}$

A Flexible Method for Conducting Power Analysis for Two- and Three-Level Hierarchical Linear Models in $\mathrm{R}$ 
Journal of Modern Applied Statistical Methods May 2014, Vol. 13, No. 1, ii-vi

$484-513$

M. LI

J. R. HARRING G. B. MACREADY

$514-518$

S. MAGGIO S. SAWILOWSKY
Copyright C 2014 JMA

ISSN $1538-9472$

Investigating the Feasibility of Using Mplus in the Estimation of Growth Mixture Models

JMASM 33: A Two Dependent Samples

Maximum Test Calculator: Excel 